\author{
KISPÁL RICHÁRD
}

richard.kispal@gmail.com

hallgató (SZTE JGYPK)

\title{
A magyarországi szerbek a század eleji sajtó tükrében (1914-1918)
}

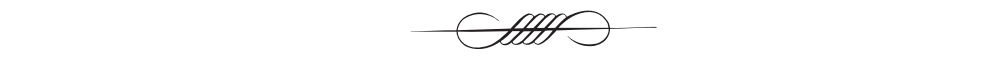

- Serbs in the Contemporary Hungarian Press (1914-1918) -

Abstract The most important military and political events of the World War I are known just like its outcome, as the historical literature has elaborately unfolded the years of war. At the same time, we are less informed about the relations between the Kingdom of Hungary and its minorities during the war. Austria-Hungary confronted primarilySerbia at the dawn of the war and this question is worth examining, since a remarkable Serbian minority of 500,000 people lived along the southern border of the Kingdom of Hungary close to the front line. The Hungarian government and the Austrian-Hungarian military leadership perceived the absurdity of the situation and its "powder keg" character, thus they were willing to make concessions for this community in order to maintain its loyalty between 1914 and 1918 .

Keywords Serbian minority, Austria-Hungary, minority politics, public opinion, press.

DOI 10.14232/belv.2015.3.8

http://dx.doi.org/10.14232/belv.2015.3.8

Cikkre való hivatkozás / How to cite this article:

Kispál Richárd (2015): A magyarországi szerbek a század eleji sajtó tükrében (1914-1918). Belvedere Meridionale 27. évf. 3. sz. 77-89. pp

ISSN 1419-0222 (print) ISSN 2064-5929 (online, pdf)

(Creative Commons) Nevezd meg! - Így add tovább! 4.0 (CC BY-SA 4.0)

(Creative Commons) Attribution-ShareAlike 4.0 International (CC BY-SA 4.0) 


\section{Bevezetés}

Az első világháború legjelentősebb katonai-politikai eseményeit, illetve végkimenetelét ismerjük, a szakirodalom és a történelemtudomány már alaposan feltárta a háborús éveket, azonban a Magyar Királyság és nemzetiségeinek háború alatti viszonyairól keveset tudunk. A Monarchia elsősorban Szerbiával került szembe a háború kirobbanásakor, ami azért is vizsgálandó kérdés, mivel egy jelentős, közel fél millió fős szerb közösség élt a Magyar Királyság déli határain, közvetlenül a front mentén ${ }^{1}$. A magyar kormány, valamint az osztrák-magyar hadvezetés érzékelte a helyzet abszurditását, illetve „tűzfészek” jellegét, így 1914 és 1918 között igyekezett engedményekben részesíteni ezen közösséget, a lojalitás fenntartása érdekében ${ }^{2}$.

De milyen is volt a korabeli közhangulat a háború kapcsán, illetve a szerb kisebbséget illetően? Hogyan vélekedett az országos és a helyi sajtó a háborúról, Szerbiáról, továbbá egyes szerb nemzetiségű állampolgárairól? Volt-e belpolitikai törésvonal a kérdés kapcsán? Nem utolsósorban pedig Szerbia és a délszlávok összességében hogyan is látták a Monarchiát? A következő tanulmánynak egy hiánypótlás a célja, feltárni eme négy év sajtóorgánumainak az álláspontját a leegyszerüsítetten definiált szerb-magyar viszony kapcsán.

\section{Módszertani keret, kutatói célok}

A kutatás módszertana két alappilléren nyugszik: párhuzamban szükséges a vonatkozó szakirodalomnak a másodelemzése ${ }^{3}$, emellett a sajtóelemzés (forráselemzés), amely

\footnotetext{
1 A horvát-dalmát területeken élő szerbeket nem beleértve.

2 Tilkovszky 1998.

3 A tanulmány elméleti keretéül TıLkovszky 1998. és GYőri SzABó 2006. munkák szolgálnak.
}

átfogó „diagnózist” képes adni a korabeli viszonyokról. A vizsgált források és szakirodalmak az 1914. júniusa és 1918. decembere közötti intervallumot ölelik fel.

A tanulmány a következő kategóriák szerint elemzi a korabeli sajtóorgánumokat: 1. Országos sajtótermékek kormány-ellenzék relációban, mint a kormánypárti Budapesti Hírlap, valamint a baloldali Népszava. 2. A térség viszonyaival foglalkozó helyi lapok, mint a Délmagyarország, illetve a Szegedi Napló. A Délmagyarországról elmondható, hogy jobbára polgári, liberális, inkább ellenzéki alapokon nyugvó lap volt a vizsgált időszakban, míg a Szegedi Napló képviselte a „nemzetibb”, függetlenségi oldalt, így a két orgánum elemzésével is egy dichotómia feltárása lehetséges. Ezen lapok forrásai azért is érdekesek, mivel nem csak országos, mondhatni nagypolitikai kontextusba helyezik a szerb-magyar kérdést, hanem helyi szinten mutatják be (Bács-Bodrog-, Torontál-, Temes-, Csanád- és Csongrádvármegye) a valós képet a két nép együttéléséről, esetleges ellentéteiről. A „szó szerint” lejegyzett és felhasznált források több esetben kapcsolódnak majd az I. világháború sorsfordító eseményeihez (a teljesség igénye nélkül), továbbá vizsgálatra kerülnek olyan „helyzetek” is, mint például az újszentiváni szerbek lojalitása, amely tényekről az utókor megfeledkezik.

Az előzetes hipotézis abban áll, hogy mind a négy napilap egy „standard” képet ad majd a világháborús viszonyokról, külön kiemelve és hangsúlyozva a hadi eseményeket, míg az olyan érzékeny problémákat, mint a nemzetiségi kérdést, csak utalásokon keresztül, „a sorok között olvasva” lehet majd értelmezni. Ezen okból a négy napilapot és forrásait külön-külön érdemes elemezni, egyenként felállítva a négy év kronológiáját, amelyek a tanulmány végére egy koherens képet adnak majd.

\section{Az országos sajtó tükrében}

A nagypolitika eltér a helyi politikától és egy-egy közösség „valóságától”, mert ideológi- 
ák és érdekek mentén igyekszik a maga igazát, létjogosultságát bebizonyítani. A századelőn egymással polemizáló ideológiák alakultak ki a magyar politikumban, mint a szociáldemokrácia (Népszava), az egyre inkább konzervatívvá váló kormány-oldal (Budapesti Hírlap), nem beszélve akár az agráriusokról, a keresztényszocializmusról, vagy pedig a politikai katolicizmusról. A legnagyobb törésvonal mindenkor a kormány-ellenzék relációban testesül meg minden politikai rendszerben, azonban a korabeli magyar helyzet ettől annyiban tért el, hogy érték alapokon egy elvileg liberális párt (kiegyezés párti liberális konzervatívok - Nemzeti Munkapárt) ált szemben ugyancsak egy liberális párttal (kiegyezést ellenző, keveslő liberálisok - Függetlenségi és '48-as Párt). A háborút megelözően „a magyar politikai elit süketet és vakot játszott, se a külső, se a belső kihívásra nem tudott megfelelö válaszokat adni. A többségészre sem vette, hogy mekkora a baj. El volt foglalva a napi politika apró-cseprő küzdelmeivel, sütkérezett saját nagyságában, élvezte a parlament gyönyörü új épületét és alapvetöen úgy érezte: minden rendben van."

A törésvonalak a nemzetiségekkel való viszonyban is megjelentek, például az 1868-as nemzetiségi törvényt ${ }^{5}$ a kormány-oldal nagy része azon okból utasította el, hogy túl sok jogot delegál át a magyartól eltérő ajkú, népeknek, míg az ellenzék annak csekély jogosítványait kritizálta. Ez a kettősség, számos esetben pedig több szálra való töredezettség, a háború éveiben is jellemző volt a politikumra, amely előrevetítette a nemzetiségekkel való megegyezés irrealitását ${ }^{6}$. A következőkben két ideológia és „szócsöve” kerül vizsgálatra, amelyekből körvonalazható, hogy miképp is vélekedett egy-egy tábor a nemzetiségekről, különösen a szerbségről.

\footnotetext{
${ }^{4}$ Megszámláltattál - A magyar tragédia előérzete. mandiner.blog.hu (http://mandiner.blog. hu/2014/07/16/megszamlaltattal_a_magyar_ tragedia_eloerzete) Letöltés: 2014.07.16 23:35.

${ }^{5}$ Az 1868. évi XLIV. nemzetiségi törvény teljes szövege. 1000ev.hu

${ }^{6}$ Katus 1993.
}

\section{I.1. BUDAPESTI HÍRLAP}

A Budapesti Hírlap $p^{7}$ 1881-ben vált ki a Pesti Hírlapból és 1938-ig jelent meg, mint konzervatív sajtóorgánum. A lap azzal az igénnyel született, hogy gyors, hiteles és világszínvonalú cikkeket, tudósításokat közöl. A Budapesti Hírlap értékrendje illeszkedett az 1867-es viszonyokat elfogadó politikai csoportosulásokéhoz, magát konzervatívként definiálva, a magyarságot pedig minden más tényező elé helyezte ${ }^{8}$. A következő alapelv volt mértékadó fennállása során: „A Budapesti Hírlapnak soha semmi körülmények között se kormánylapnak, se pártlapnak nem szabad lennie. Az egész magyar közönség lapja legyen, független nemzeti irányú, jelszava: a magyarságért!"

A többi vizsgált sajtóterméktől eltérően a Budapesti Hírlapnak az 1914-es számai kerülnek a kutatás első részének fókuszába, mivel a háború kitörésekor a kormánypárti lapnak konkrét szerb képe létezett és ezen orgánum képviselte a „mainstream-vonalat”.

Az elemzést érdemes a szarajevói eseményeket követően kezdeni. 1914. július 1-jén „Az országgyülés részvéte” című gyászhír a következőképp emlékezett meg a meggyilkolt uralkodói párról: „Hosszú idő óta most először volt egységes a magyar országgyülés képviselöháza. Egységes a gyász és az öszinte fájdalom érzésében. Nagy csöndben, szinte nesztelenül gyülekeztek a képviselők. Munkapártiak és ellenzékiek egyaránt, fekete ruhában jöttek el. ${ }^{9}$ " Ugyanezen számban megjelent "A nyelvkérdés a közigazgatásban” címü cikk, amely a Tisza-kormány kisebbségpolitikájának elveit körvonalazta: „... Nem tüztek ki maguknak más célt, mint jó közigazgatás teremtését, a mely egyúttal a legjobb nemzetiségi politika is. Ezért

\footnotetext{
${ }^{7}$ Budapesti Hirlap 1914-1933. Forrás: Arcanum Digitális Tudománytár (http://adtplus. arcanum.hu/hu/collection/BudapestiHirlap/) Letöltés: 2014. július 7. 10:28.

8 Cieger 2001.

${ }^{9} \mathrm{Az}$ országgyűlés részvéte. Budapesti Hírlap 34. évf. 153. sz. 2-3.
} 
éppen a legexponáltabb nemzetiségi területeken a legjobb közigazgatási tisztviselőknek kell müködniük, hogy szakbeli rátermettségükön kívül az illetö nem magyar nyelvben való jártasságuk és a nem magyar ajkú lakossággal való igazságos és humánus bánásmód útján hatásos ellensúlyt képviseljenek a nemzetiségi izgatásokkal szemben. ${ }^{10}$ "Tehát a merényletből is kiindulva, ekkor már a politikai elit a gyakorlatban érzékelte a nemzetiségek egyre radikálisabb törekvéseit, amelyet közigazgatási engedményekkel kísérelt meg mérsékelni (a Tisza István vezette kabinet az I. világháború alatt több engedményben részesítette a háborúban is hatványozottan érintett nemzetiségeket).

A „kormánylap” szerb képét az alábbi cikkek hivatottak bemutatni. 1914. július 18-án „Szerb egyházi autonómia és a szerb pártok" címmel a következő vizsgálandó cikk jelent meg, amely magába foglalja a magyarországi szerb politikumról alkotott negatív képet is. „Mi azt véljük, hogy itt elsősorban nem a szerb nép a hibás, illetve ez egészen ártatlan, hanem bünösök azok, kik évtizedek óta egyéni önzö és anyagi érdekből a szerb nép vezéreiül feltolták és jelenleg is állandóan feltolják magukat. Bünösök a szerb radikális- és szerb liberálispártnak megöszült vezérei, kik elött a szerb egyházi autonómia csak kenyér-kérdés, mert belöle, illetve kríziséből tartják fönn magukat már 1868 óta, belöle éltek és élnek. A fiatalabb nemzedékeknek itt nincs beleszólása. Ilyen erkölcstelen alapulnak, sajnos, a mi régi szerb pártjaink...11" Áttérve a háborút közvetlenül megelőző napokra, július 27-én a magyar közvélemény a következőképp fogadta a Szerbia elleni mozgósítás híreit: „Nagy föltünést keltett a mozgósítási parancs. A mikor a plakátokat kiragasztották, tízével, húszával állták körül az emberek és lelkes hangon tárgyalták a bekövetkező eseményeket. Minden sarkon, minden

10 A nyelvkérdés a közigazgatásban. Budapesti Hírlap 34. évf. 153. sz. 5.

11 Szerb egyházi autonómia és a szerb pártok. Budapesti Hirlap 34. évf. 168. sz. 1. szögleten csoportok verödtek össze és harsogott az éljen. Mihelyst egy katonai csapat elvonult, lelkesen köszöntötte a közönség. A férfiak éljeneztek, a nők a kendöjüket lobogtatták. ${ }^{12 " ~} \mathrm{Az}$ idézett szöveg alapján megállapítható, hogy a magyar közvélemény egyértelmüen a háború mellett foglalt állást, azonban a sajtó hasábjain ez a „militáns-vágy” nem közvetlenül a szerbekkel szemben élt (főképp nem a magyar állampolgársággal rendelkező szerb közösség ellenében), hanem lényegében a nemzeti büszkeségből táplálkozott (1914. július 28-i vezércikk: „A népszerü háborúl ${ }^{13}$ ”).

A háború kirobbanása tekinthető egy délszláv egységesítési törekvést megelőző csapásának is a Monarchia részéről, amit „A szerbek bünlajstroma" című cikk tartalma is megkísérelt alátámasztani: „A Narodna Obrana nemcsak a szerbiai lakossághozfordult, hanem a monarkiának délszláv nemzetiségü polgáraihoz is. A monarkia délszlávok lakta területeit szerb területnek tekintette. A Narodna Obrana föfeladatát abban látta, hogy Szerbia területén kívül lakó testvéreket a részvételre bírja. (...) A Narodna Obrana... a harcot prédikálja Ausztria és Magyarország ellen a szerb népnek azzal az ürüggyel, hogy a monarkia megrabolja a szerbeket szabadságuktól és nyelvüktől és meg akarja őket semmisiteni. ${ }^{14 "}$

Július 28-án megérkezett a Monarchia hadüzenete Szerbiának, amit az I. világháború kezdődátumának tart a történelemtudomány, de miképp is jelent meg ez az esemény a $\mathrm{Bu}$ dapesti Hírlap hasábjain? Július 29-én született meg az az ismert manifesztum, amelyet Ferenc József intézett népei felé, Tisza István aláírásával támogatva: „A határon bünös áramlat csap át, a mely a monarkia délkeleti részén az állami

\footnotetext{
${ }^{12}$ Magyarország harci kedve. Budapesti Hirlap 34. évf. 176. sz. 8.

13 A népszerü háború. Budapesti Hírlap 34. év. 177. sz. 1.

${ }^{14}$ A szerbek bünlajstroma. Budapesti Hírlap 34. évf. 177. sz. 8.
} 
rend alapjainak megingatására, a népnek, melyről olyan atyai szeretettel gondoskodom, az uralkodóház és a haza iránti hűségtől való eltántorítására $s$ az őrület és a hazaárulás bűnös tetteire való fölizgatására irányul. (...) Ezt a tűrhetetlen aknamunkát meg kell állítani, Szerbia ezen folytonos kihívásainak véget kell vetni... ${ }^{15}$ " Az uralkodó és az osztrák-magyar politikai elit a birodalom egységére, területi integritására és a merényletre hivatkozva ezen manifesztummal a hadüzenet legitimitását kísérelte meg bizonyítani mind a nemzetközi közvélemény, mind pedig a soknemzetiségü Monarchia felé - azonban óvatosan ügyelt arra, hogy „saját” délszlávjait ne sértse meg.

Végül a háború gyors sikereinek vágyát szertefoszlatta az a tény, hogy a szövetségi rendszerek miatt a lokális konfliktus globális szintre is kiterjedt, a Monarchiának pedig több fronton kellett helytállnia. Az augusztus 23-án megjelent „A monarkia és ellenfelei. A gyilkos szerbek." címü cikk is mutatja, hogy a sajtó, illetve a közvélemény ekkor már kezdte felismerni a július végén kirobbant háború elhúzódását és annak valódi hátterét-tétjét: „Ha a hadjárat sorsát egyáltalán Szerbiában lehetne eldönteni, akkor már el is döntöttük volna. De Európa sorsa és a minek is, és Szerbiáé is a francia-német, ránk nézve különösen az orosz harctéren fog eldülni. Miután Oroszország beavatkozott a monarkia és Szerbia között kitört harcba, kénytelenek voltunk egész erönket az északkeleti harctéren összevonni. Ezzel a Szerbia ellen való háború, melyet a közvélemény legnagyobb része büntetö expedíciónak tartott, automatice mellékakcióvá lett, mely a nagy döntést alig érinti. ${ }^{16 "}$

\section{I.2. NÉPSZAVA}

A századelő egyik legjelentősebb politikai csoportosulása a munkásmozgalom volt,

${ }^{15}$ A király manifesztuma. Budapesti Hirlap 34. évf. 178. sz. 1.

${ }^{16}$ A monarkia ellenfelei. - A gyilkos szerbek. - Az offenzíva fölfüggesztése. Budapesti Hirlap 34. évf. 203. sz. 2. amelynek hazai irányzata „idegen eszméket importálva" kísérelte meg a magyar társadalom alsóbb osztályainak érdekeit képviselni (szociális problémáit orvosolni), az internacionalizmus jegyében, más kontextusba helyezve a nemzetiségi problémát. Ennek a politikai csoportosulásnak, illetve a Magyarországi Szociáldemokrata Pártnak volt az 1877-ben alapított „szócsöve” a Népszava, amely napjainkban is megjelenő napilap.

$\mathrm{Az}$ elemzést megelőzően a tanulmány néhány gondolatban ki kell, hogy térjen a baloldalnak a kisebbségekkel kapcsolatos álláspontjára is a dualizmus és a világháború éveiben. A szociáldemokrácia azon okból volt képes nóvumként megjelenni a magyar társadalom életében, ezen túl gondolkodásában, hogy osztályalapon, nem pedig nemzetiségi viszonylatban kísérelte meg felkarolni a közösség problémáit ${ }^{17}$. Tehát a baloldal nem tett különbséget a magyar és a szerb munkás között, így kisebbségpolitikai vonatkozásban is gyökeresen más elképzelései voltak, mint az 1918-ig hatalmon lévő politikai elitnek. Igaz voltak olyan sarokpontok, mint az autonómia megadásának a kérdése, amit a baloldal ugyanúgy elutasított, mint a regnáló politikai elit, mivel azt gazdaságilag károsnak - és szükségtelennek - tartotta. A világháború kirobbanása mellett való rövid ideig tartó kiállást követően a Népszava, illetve a szociáldemokrata szervezetek is ellenezték a háborút (a pacifizmust képviselve), mivel azt az imperializmus eszközének tartották, sőt 1917-től szimpatizáltak az orosz forradalommal (amitől a magyar elit „rettegett”). $\mathrm{Az}$ őszirózsás forradalom után a korábban háttérbe szorított politikai csoportosulások számára megnyílt az út az ország irányítása felé, ami hamar átfordult a Tanácsköztársaság diktatúrájába, mikorra Magyarország területe olyannyira leszűkült, hogy nem volt lehetősége a nemzetiségi kérdésben vallott álláspontjának a gyakorlati megvalósítására.

Az első vizsgált cikk 1914. július 3-án

17 G. Fodor 2004. 
született, amely közvetlenül Ferenc Ferdinánd trónörökös meggyilkolása utáni közhangulatot tükrözte. Eszéken július 2-án „mintegy ötven fiatalemberből álló csoport zajosan tüntetett a szerbek és a szerb-horvát koalíció ellen. A tüntetők több ablakot bezúztak, majd a király éltetésével és a szerbek abcúgolásával elvonultak. A rendörség végül szétzavarta a tüntetőket. Djakovoban tegnap este megújultak a szerbellenes tüntetések. Sokszáz fönyi embertömeg ily kiáltásokkal: Le Szerbiával! Le a gyilkosokkal! Dicsőség Ferenc Ferdinánd emlékének!18” A háborút megelőző és a hadüzenetet követő egy évben ideológiától függetlenül, a magyar politikai erők nagy része egységesen vallotta a Szerbiával való leszámolás szükségességét, így a baloldal is, azonban a háború utáni rendezés terveiben már eltérések voltak tapasztalhatóak (1915-1916-ban már kikristályosodott az ellentét).

1916-tól a baloldal és a Népszava is egyre inkább a gazdasági, szociális és társadalmi reformok sürgetését, a választójog kiterjesztését, illetve a háború mihamarabbi befejezését szorgalmazta, amely miatt újra fókuszba kerültek az ideológiai ellentétek. A Népszava 1917. szeptember 5-i számában „A választójogért!” címü rövid hír jelent meg, amely a vizsgált térség aktivitását is jelzi: „Az újvidéki választójogi blokk elnöksége szeptember 23-án Újvidéken nagyszabású választójogi népgyülést rendez, amelyen a választójogi blokk központi vezetöségének számos tagja is részt vesz. ${ }^{19 "}$ "Ugyanezen címmel jelent meg a szeptember 7-i, majd 8-i számban Vásárhelyen és Aradon is egy felhívás, amely népgyüléseken már Károlyi Mihály és Vázsonyi Vilmos, választójogi miniszter is jelen volt. A helyszínek megválasztása azért kiemelkedően fontos, mert mind Újvidék, mind pedig Arad térségében jelentős létszámú szerb, valamint román kisebbség élt, ezért a választójog kiterjesztésének terve számukra gesztusértékkel bírt.

18 A szerbek ellen. Népszava 42. évf. 155. sz. 6.

19 1917. szeptember 5.: A választójogért. Népszava 45. évf. 223. sz. 7.
Végül az összeomlás, majd a történelmi Magyarország alkotóelemire hullásának évéből, 1918-ból került vizsgálatra egy-egy cikk. 1918. november 29-én megjelent egy hír, amely egyszerre két délszláv kisebbség, a szerbség és a bunyevácok a magyarsághoz füződő viszonyát, esetleges lojalitását festi le. „A zombori bunyevácok nem haladnak együtt a szerbekkel” a következő információt foglalja magában: „A zombori szerb nemzeti tanács gyülést tartott, amelyre a bunyevác polgárokat is meghívták, hogy a szerb és a bunyevác nemzeti tanács müködésének további irányt szabjanak és sorsukat megbeszéljék. A gyülésen a szerbek nagy számmal jelentek meg, a bunyevácok azonban nem mentek el oda. Pastrovics Iván, a zombori bunyevác nemzeti tanács ügyvezetö elnöke írásban bejelentette, hogy a bunyevácok nem óhajtanak részt venni a gyülésen és ha ott bunyevác kiküldötteket választanak meg, azok ezt a megbizatást nem fogadják el és nem mennek el Újvidékre, a délszláv állam megalakulásának kikiáltására. ${ }^{20 "}$

A gondolatmenet zárásául egy 1918. december 13-i hírblokk szolgál, amelyben a Népszava a „Magyarország területe és az új szomszédok" rovatban sorra veszi a szerbek által megszállt területeken zajló folyamatokat, amelyek tisztán tükrözik az impériumváltást. "A szerbek átveszik a törvényszéket” címü hírben a szabadkai és a környékbeli törvényszékek jogfolytonosságáról esik szó, ahol "hivatalos nyelvként a szerbet jelölték meg”. A „Temesvárott tilos a gyülekezés” hír arról számol be, hogy „... a szerb föparancsnokság elrendelte, hogy a városban tilos mindenféle politikai vagy egyéb gyülekezés. Gyüléseket csak kivételes esetekben, a térparancsnok engedélyével és kiküldöttjének jelenlétében szabad tartani. Az engedelem nélkül tartott gyülések rendezőit és összehívóit szigorúan büntetik." A magyar kormány visszaszorulását és a terület elvesztését bizonyítja az utolsó vizsgált,

\footnotetext{
${ }^{20}$ A zombori bunyevácok nem haladnak együtt a
} szerbekkel. Népszava 46. évf. 283. sz. 8. 
„A magyar kormány rendeletei a megszállott területeken végre nem hajthatók”, címü rövidhír: „Zomborból jelentik: Dr. Bugarszky Koszta Bács-Bodrog vármegye és Zombor város fóispánja átiratot intézett a megyei hatóságokhoz, amelyben értesítik őket, hogy a további intézkedésig a magyar népkormánytól érkezö törvények, rendeletek vagy bárminemü más intézkedések végre nem hajthatók és az ottani hatóságok a magyar népkormányhoz semmiféle jelentést nem tehetnek. ${ }^{21 "}$

\section{Délszlávok - fóképp a szerbség - a kora- beli helyi magyar sajtóban}

Az országos és a helyi lapok ekkortájt megjelent kiadványairól általánosságban elmondható, hogy napról-napra, folyamatosan a nagyobb horderejü eseményeket vizsgálták, mint Ferenc Ferdinánd halála, a hadüzenet, vagy pedig a front történései, azonban „elvétve" megjelentek a magyarországi szerbekről is hiteles, a tanulmány szempontjából pedig releváns tartalmak. A helyi sajtó napi szinten föképp a háború első két évében „cikkezett” Szerbiáról, ameddig a déli front fennállt és a délszláv állam nem kapitulált, illetve 1918 szeptemberében újra nem lett a Monarchiával szemben hadviselő fél és kezdte meg DélMagyarország megszállását (francia csapatok segítségével). Ezen okokból a két helyi lap által közölt vonatkozó cikkeket szükséges feltárni, kronologikusan párhuzamos módon elemezni - amelyek eltértek a „mainstream” - országos történésektől.

\section{II.1. DÉLMAGYARORSZÁG}

A Délmagyarország hasábjain a háború előestéjén és kitörésekor számos cikk jelent

\footnotetext{
21 A szerbek átveszik a törvényszéket. Temesvárott tilos a gyülekezés. - A magyar kormány rendeletei a megszállott területeken végre nem hajthatók. - A szerbek föloszlatták a nemzeti tanácsokat. (Népszava 46. évf. 295. sz. 3.
}

meg napi szinten Szerbiáról, közvetve pedig a délszlávokról, így a magyarországi szerbekről is. A Délmagyarország, mint helyi napilap „Vonzáskörzetébe"22 olyan nagyobb városok tartoztak, mint Szeged, vagy Szabadka, amelyeket övező kisebb településeken jelentős szerb közösség élt, így a közbeszédben nem csak nagypolitikai, de helyi szereplőként is jelen volt a szerbség (Ókeresztúr, Ó- és Újszentiván). Az első vizsgált tudósítás 1914. augusztus 12-én jelent meg „Hogy dolgozott Szerbia a monarchia egysége ellen” címmel. Ismert, hogy a szarajevói merényletet követően a Monarchia 1914. július 23-án egy ultimátumot $^{23}$ fogalmazott meg Szerbia felé, amelyben több teljesíthetetlen feltételt is szabott, többek között a Narodna Odbrana szervezetnek az azonnali felszámolását, amelynek célja egy egységes délszláv állam megteremtése volt. A tudósítás a következőket írta Magyarország déli határai és lakosai kapcsán: „A Narodna odbrana főfeladatai közé tartozik, közeli és távoli, a határon túl lakó testvéreinkkel és a világon lévő többi barátunkkal való összeköttetés. Ezen a szón - nép - a Narodna odbrana egész népünket érti, nem csak a szerbiait. ${ }^{24 "} \mathrm{~A}$ tudósítás szerzője egyértelműen megfogalmaz-

${ }^{22}$ Közvetve pedig a lap érintette az újvidéki, a zombori, de még az aradi eseményeket is.

${ }^{23}$ A Monarchia ultimátuma Szerbiának: „2. azonnal feloszlatja a Narodna Obranának nevezett egyesületet, elkobozza propagandájának összes eszközeit, és hasonlóan fog minden olyan társaság és szervezet ellen eljárni, amely az Osztrák-Magyar Monarchia ellen irányuló propagandával foglalkozik; a királyi kormány gondoskodni fog róla, hogy a feloszlatott egyesületek más név alatt és más formák között ne folytathassák müködésüket." Forrás: Az OsztrákMagyar Monarchia felbomlása. tudasbazis. sulinet.hu (http://tudasbazis.sulinet.hu/hu/ tarsadalomtudomanyok/tortenelem/magyartortenelmi-terkeptar/az-osztrak-magyarmonarchia-felbomlasa/forrasgyujtemeny) Letöltés: 2014. július 15. 16:12.

${ }^{24}$ Hogy dolgozott Szerbia a monarchia egysége ellen. Délmagyarország III. évf. 198. sz. 3. 
za azt a korabeli közhangulatot a térségben, hogy Szerbia nem csak a szerblakta „földre” tart igényt, de feltehetően magyar és más nemzetiségek lakta területeket is kiszakítana a Monarchiából. Ugyanezen számban azonban egy ellentmondás is tapasztalható; a rövid hírek között szerepel „ $A z$ ókeresztúri szerbek hazafiassága” címmel egy rövid írás, amely a helyi szerbek lojalitását tükrözi, tehát szó sem esik esetleges szeparatizmusról. „A mostani viszonyok között kétségtelenül a legnehezebb helyzetben vannak azok a szerb nemzetiségek, akik Magyarországot vallják hazájuknak és magyar érzelmeket táplálnak lelkükben. Pedig, hogy a délvidéki szerbek nagy része milyen hazafiasan viselkedik, azt élénken illusztrálja az ókeresztúri szerb hitközség közgyülése, mely egyhangúlag, nagylelkesedéssel a Vörös Kereszt Egyesület támogatására ezer koronát szavaztak meg, a hadba vonult katonák családtagjai részére pedig 500 koronát. ${ }^{25}$ "

Az 1914-es év „lelkesedését” és kezdeti sikereit követően a villámháború állóháborúvá vált, ami a közhangulaton, illetve az azt megtestesítő helyi sajtón is észrevehető változást eredményezett. 1915-ben már zajlott a totális háború, a Monarchia több fronton harcolt, így Délvidéken a szerbekkel, Északkelet-Magyarország térségében pedig az oroszokkal kellett szembenéznie, amit a helyi lakosság is megszenvedett. 1915. szeptember 2-án „A Délvidék elpusztult községei" címmel egy olyan rövid tudósítás látott napvilágot, amelyben a régió magyar és német lakta falvainak megsegítését helyezi elötérbe a szerző, míg a szerb lakosokról említést sem tesz (holott több esetben az említett községekben nagy arányban jelen voltak, akár többséget is alkotva, például a Szerémségben). „... a Délvidék lakosságának segítésére nem gondol senki. Egyszerre elfelejtkezett mindenki az összelött zimonyi, pancsovai, mitrovicai, orsovai házakról, senki sem gondol a háborúnak délen lakó árváira. (...) Az országos

\footnotetext{
${ }^{25} \mathrm{Az}$ ókeresztúri szerbek hazafiassága. Délmagyarország 3. évf. 198. sz. 4.
}

mozgalom vezetőinek gondoskodnia kellene, hogy az összegyűlő összeg felesleges részét az összelövöldözött délmagyar városokban lakó magyarok és németek házainak újjáépítésére fordítsák. ${ }^{26 "}$

A Délmagyarország hasábjain kialakult „szerb-képet” - amelyet olvasói előtt is feltárt, akik feltehetőleg azonosulni tudtak vele - érdemes az 1917-es és 1918-as cikkek elemzésével folytatni, amikor a hadiszerencse és a háború állása már a központi hatalmak vereségét prognosztizálta, (negatívan) meghatározva így a kisebbségekhez való viszonyt is. Igaz Szerbiát ekkor még a központi hatalmak ellenőrzésük alatt tartották, emiatt a sajtó inkább más frontok eseményeivel foglalkozott, azonban érzékelhető volt már a társadalomban az összeomlás közelsége, a háború utáni rendezésektől való félelem, illetve egy elhúzódó politikai válság. A „nemzetiségi veszélyről” és a választójog kiszélesítéséről dr. Kelemen Béla, 1917. júliusában kinevezett föispán, a következő véleménynyel volt („A föispán esküje és beszéde”): „.. az aggodalmaskodók gondolják meg, hogy ha az annekszió és a hadikárpótlás nélküli világbéke a maga teljes következetességével, határkiigazitások nélkül jön is létre és Románia és Szerbia a háború elötti terület-határok között állíttatnak helyre, a területhatárok hiába lesznek a régiek, nem a régi Románia és a letört Szerbia lesznek a mi szomszédaink, hanem a letört Románia és a letört Szerbia, amely szomszédos államoknem fognak többé a hazai oláh és a szerb anyanyelvü lakosságra oly vonzó eröt gyakorolni, mint gyakoroltak a háború előtt. Ma már ő maguk is és a mi nemzetiségeink is teljes ismeretében vannak a tényleges eröviszonyoknak. ${ }^{27}$ "Tehát a főispán 1917 derekán még egyértelműen a magyarság szupremáciáját tartotta reálisnak, nem is gondolva az esetleges területi változásokra, lebecsülve a nemzetiségek önszerveződését

\footnotetext{
26 A Délvidék elpusztult községei. Délmagyarország 4. évf. 213. sz. 5.

27 A föispán esküje és beszéde. Délmagyarország 6. évf., 176. sz. 6-7.
} 
és kulturális, politikai, ezen túl társadalmi fejlettségét, nem utolsósorban anyaállamaik katonai potenciálját.

1918 szeptemberében, amikor már csak idő kérdése volt a vereség beismerése, a térségben közigazgatási határmódosításokkal kísérelték meg az etnikai arányok átrajzolását, amely napjainkig bevett gyakorlat a többség irányából a kisebbség homogén tömbjeinek megbontása érdekében. A „Szeged vármegye” címü cikk a következő gondolatmenetet állította fel, amely kijelentések célja egyértelmüen a nemzetiségek mihamarabbi asszimilálása volt: „Szeged szabad királyi város székhellyel alakittatnék egy vármegye. Ezen vármegye lakossága 409398 lélek lenne: ebből 260201 magyar, 18612 német, 13755 tót, 23178 oláh, 83836 szerb stb. - mindez lehetövé teszi azt, hogy az ország ezen legnépesebb, tősgyökeres magyar városa, a magyarság asszimiláló képességét érvényesithesse a délmagyarországi nemzetiségi vidékeken. Igazán botor politika az, amely a nyelvterületi határoknál vonja meg a közigazgatási területi határt. Igy Bácskábólés Torontálból 86000 szerb anyanyelvü magyar állampolgár elvonva lesz az újvidéki és a nagykikindai szerb agitátoroktól és a legnagyobb vidéki magyar város kultúrájának égisze alá kerül. ${ }^{28 "}$

1918 őszétől a Monarchia fokozatosan vonult vissza a megszállt Szerbiából, szeptemberben Bulgária különbékét kötött (1918. szeptember 29.), így a szerb államnak lehetösége nyílt nagyobb területek birtokba vételére a segítségére érkező francia csapatokkal öszszehangoltan. A sajtóban aggodalomra nem is a szerb elörenyomulás, hanem a román és a cseh koncepciók adtak okot, amelyek hatalmas részeket kívántak kiszakítani az országból, ellenben a szerblakta területek Szerbiának való átadását a közvélemény nem tartotta elfogadhatatlannak ${ }^{29}$. 1918. október 28-án

28 Szeged vármegye. Délmagyarország 7. évf., 201. sz. 3.

29 Ellenben ekkortájt senkiben sem fogalmazódott meg, hogy esetleg magyar, vagy német „megkezdték Délmagyarország katonai kiürítését, illetöleg a katonai raktárak és berendezések Magyarország belsejébe való szállitását ${ }^{30}$ ", azaz az újonnan megalakult magyar kormány kénytelen volt a mai államhatárnál is mélyebben visszavonni csapatait (a belgrádi katonai konvenció értelmében), így megnyílt az út Szerbiának a magyarországi, szerbek és más népek által lakott, területek megszállása, majd egységes államba történő beolvasztása felé.

\section{II.2. SZEGEDI NAPLÓ}

A Délmagyarország áttekintését követően egy másik helyi lap, a Szegedi Napló (továbbiakban Napló) által körvonalazott „szerb-kép” is segít a két nép korabeli viszonyának feltárásában. A Napló, eltérően a Délmagyarországtól, magát politikai, közgazdasági és irodalmi napilapként definiálta, így a háborús események is másképp jelentek meg oldalain, mint az előbb vizsgált „haditudósítás” jellegű lapnak. A lap „nemzetibb” jellege révén a magyarság, mint Kárpát-medencei államszervező erő és államának integritása is nagyobb hangsúlyt kapott.

Az első vizsgálandó Napló cikk közvetlenül a Ferenc Ferdinánd ellen elkövetett merénylet után jelent meg, 1914. július 1-jén, „A bünbarlang” címmel. „Amúgy is tizenhat nyelven beszéltek már Magyarországon és Ausztriában együtt a népek, volt már köztük szláv elégés nem volt szükség a szaporításukra. S a Balkánon az évek során erösen megváltozott a helyzet. A délszláv államok tüzei kigyulladtak. Szerbia megerősödöttés evés közben megjött az étvágya. Neki kellene Montenegró is, kellene Bosznia és Hercegovina is, kellene még Horvátország is. Ezért a célért tülekedik és ebben az aknamunkás harcban minden eszközt jónak lát, amely segíti. Fanatizmusa vad... ${ }^{31}$ " A kiemelt szöveg

többségű területek is délszláv fennhatóság alá kerülnek.

30 Megkezdték Délmagyarország katonai kiürítését. Délmagyarország 7. évf. 256. sz. 6.

31 A bünbarlang. Szegedi Napló 37. évf. 155. sz. 1. 
tisztán jelzi a szerb nacionalizmus erősségét, illetve azzal párhuzamban a Monarchiában megnövekedett (dél)szláv elem arányát, ami veszélyezteti a történelmi Magyarország integritását - a szerző és a közvélemény szerint is. A cikk szerzője továbbá a Dél-magyarországi szerbeket, horvátokat káros, mondhatni „nemkívánatos” elemként definiálja, akik az örök instabilitás okai.

A háború következtében kialakult helyzet, a menekülthullám leírására, valamint a (lojális) szerbség és a történelmi Magyarország (az állam) viszonyának bemutatására a következő, 1914. október 6-i, „A szerb pópa búcsúztatója a bitófa elött" címü rövid hír a legalkalmasabb: „Ismeretes dolog, hogy amikor csapataink kivonultak Pancsova városából, az ottani szerbek egy része nemcsak örömmel és ebéddel várta Petár király toprongyos leventéit, hanem idöközben ki is rabolták a menekülö magyarok házait. (...) Két szerb földmüves, akiket nem értek tetten, most került haditörvényszék elé. Halálra itélték őket, s holttestük mellett a szerb pópa a következőket mondta: Isten nagy és hatalmas. Ereje világokat dönget és nemzeteket dönt porba. A Mindenható szent és kegyelmes. Megbocsátja a bünök sokaságát és vétkek milliárdjait. Csak egyet nem bocsájt meg az Úr, a hazaáruló vétkét. Az a legrettenetesebb bün. Szeressétek tehát ezt a földet, amely kenyereteket adja s amelyben atyáitok hamvai porladnak. ${ }^{32}$ "A hírhez kiegészítésként feltétlen meg kell említeni, hogy a magyarországi szerb közösség identitásának és nemzeti tudatának ápolásában kulcsfontosságú szerepe volt az ortodox egyháznak, amely több esetben szembehelyezkedett az államhatalommal. Az előző hírben az ortodox pópa mégis a lojalitást és a hazaszeretet helyezi elötérbe, szemben a szerb identitással, ami annak is tulajdonítható, hogy a kisebbség hüségének bizonyításával kísérelte meg a jogkorlátozást elkerülni (például katonai közigazgatás).

32 Szerb pópa búcsúztatója a bitófa előtt. Szegedi Napló 37. évf. 254. sz. 6.
1915 szeptemberében az állam és a nemzetiségek viszonyát hitelesen tükrözi Ferenc József üzenete Magyarországnak, illetve Tisza István, miniszterelnöknek az arra adott válasza („A hódoló küldöttség. Üzent a király Magyarországnak”). A császár, idealisztikus módon a következőképp látta a birodalom és a Magyar Királyság, illetve a nemzetiségek relációját: „A mai nagy megpróbáltatások jobban, mint valaha kitünt, hogy a kibékités és a kiegyenlités e müve népeim lelkét, különösen magyar koronám népeiét is teljesen áthatotta. Midőn ellenségeink hódító szándékkal megtámadtak, a magyar és a horvát nemzet egynek érezve magát a koronával, testvéri vetélkedésben többi népeimmel, lelkes elszántsággal és ereje teljes megfeszitésével vette fel hívó szavamra a küzdelmet a reánk törö túlerő ellen. Elnémult az országban minden politikai viszály: az ország összes nemzetiségei egybeforrtak a haza lángoló, minden áldozatra kész szeretetében. ${ }^{33}$ " Ferenc József távirata inkább szolgált arra, hogy a Monarchia stabilitását mutassa a külvilág felé, illetve gesztusként megköszönje a nemzetiségeknek, hogy nem fejtenek ki ellenállást a birodalom érdekeivel szemben, mint hogy a valós helyzetet feltárják (lásd. belpolitikai válság, titkos tárgyalások a nemzetiségek vezetôi és az anyaállamok között).

A háború végéhez közeledvén megjelentek olyan alternatívák is a nagypolitikában, mint például 1917 decemberében, amikor a Tisza István vezette külügyi delegáció tárgyalta a háború utáni rendezés módozatait. A Napló 1917. december 8-i számában „A delegációk” címmel a következő összefoglalót közölte: „Tisza Istvánnak ma is az az álláspontja, amely némelyek szerint az egész világháború gyújtószikrája volt: Szerbiát el kell zárni a tengertöl, úgy, hogy gazdaságilag teljesen a monarchiára legyen szorulva. (...) Tisza István grófpolemizál Andrássyval. Azt kívánja, hogy Bulgária Szerbiával és Romániával szemben határkiigazitást

${ }^{33}$ A hódoló küldöttség. Üzent a király Magyarországnak. Szegedi Napló 38. évf. 211. sz.3-4. 
nyerjen. Kijelenti, hogy veszedelmet lát abban, ha Szerbia az Adrián megveti a lábát. ${ }^{34 "}$

A helyi sajtóorgánumok elemzésének zárásaképp Tisza István 1918. október 17-i nemzetgyülési beszédét szükséges megvizsgálni, amely október 18-án jelent meg a Naplóban a „Képviselőház ülése” címmel: „Azoknak a nemzetiségeknek nagyrésze, melyek nem tartoznak sem a magyar, sem a német fajhoz, szintén hüséggel illeszkedik be a nemzet keretébe, és csak elenyészö kisebbség az, amely azzal szembehelyezkedik. (...) Sohasem voltunk a nemzetiségek elnyomói! $!^{35}$ " Az idézett beszéd korabeli kontextusba helyezve számos ponton állít valótlanságot, illetve utal rossz helyzetfelismerésre. Ekkor már nem Tisza volt kormányon, így a magyar kisebbségpolitika inkább korlátozó, mint adakozó képet képviselt a nemzetiségek szemében. 1918 októberére a környező államok megkezdték a nemzetiségek és egyben magyarok lakta vidékek megszállásának előkészületeit, amely ellen a válságban lévő magyar politika nem volt képes konstruktív alternatívát felmutatni.

\section{Konklúzió}

Az 1914-es évre az erőteljes szerb állami propaganda, Szerbia regionális törekvései, valamint a szerb kisebbségnek a nacionalizmusra való fogékonysága önmagában hordozta a háború lehetőségét, amit csak erősített az a tény, hogy a Monarchia nemzetközi tekintélye és katonai potenciálja egyre csökkent a XIX. századhoz viszonyítva. 1914 júliusának eredményeképp a korabeli sajtóorgánumok mind kiálltak a trónörökös meggyilkolását követően a háború szükségessége és létjogosultsága mellett, azonban kivétel nélkül

\footnotetext{
34 A delegációk. Szegedi Napló 40. évf. 280. sz. 4.

35 A képviselőház ülése. Szegedi Napló 41. évf. 240. sz. 2.
}

egy lap sem támadta nyíltan a magyarországi délszlávokat ${ }^{36}$.

A háború kirobbanását követően az országos lapok rendre Szerbia azon agitációjáról számoltak be, amelyben igyekeznek a délszláv egység víziójának megfelelően minden szerbet és rokon népet egy államban egyesíteni, ami aggasztotta a magyar elitet. Mindkét helyi lapban jelentek meg olyan cikkek, amelyekben például az újszentiváni szerbek anyagi támogatást nyújtottak a rászorulóknak a háború éveiben, vagy a Magyar Királyság mellett való kiállásról tanúskodtak, ellenben az ellenkező magatartásra is volt számos példa, főleg a szerb megszállást követően. Egyértelmüen nem jelenthető ki, hogy a szerbekben ne lett volna jelen a szeparatizmus vágya (mint minden nemzetben ekkortájt - önrendelkezés igénye), azonban a magyarsághoz is szoros történelmi, kulturális, nem utolsósorban pedig gazdasági kapocs füzte. Összességében a magyarországi szerbség álláspontja az elszakadás kapcsán divergáló volt, amely antinómiát a Monarchia katonai vereségének ténye számolt fel, mikortól a szerb csapatok francia segítségével egyszerüen megszállták a Szerbiával való egyesülésre „ítélt" területet.

A sajtóelemzést követően, mint ahogy már a tanulmány korábbi szakaszaiban is kitünt, a magyar közvéleményről egyértelmüen nem mondható el, hogy szerbellenes lett volna (magyarországi szerbekkel szemben kevésé negatív kép). Ideológiákra bontva a baloldal egyáltalán nem volt „kisebbségellenes”, míg a kormányzat is „puha” eszközökkel kísérelte meg a kérdést rendezni, amely a szerb nemzetiséggel való viszonyban is tükröződött (egyházi autonómia, oktatás, sajtó, gyülekezési jog - uszító szervezetek betiltása). Igaz a Szerbiával szemben való revans vágya a merényletet követően az egész magyarságban élt, amely olyan kellemetlen jelenségekkel is párosult, mint a szerb nacionalizmustól (jugoszláviz-

\footnotetext{
36 A röplapokat és a radikális politikai sajtóter-
} mékeket nem beleértve. 
mus) való félelem, vagy Szerbia regionális „kihívó” szerepben történő megjelenése - de mindezek egy „egyszerü, rövid” háborút követően nem lettek volna meghatározóak a két nép viszonyában. Maga a világháború a kölcsönös garanciaegyezmények miatt robbanhatott ki: azok után, hogy a Monarchia hadat üzent Szerbiának, az Orosz Birodalom rögtön garanciát vállalt szövetségese megsegítésére, nagyhatalmi konfliktussá generálva két állam lokális ellentétét, amiben az osztrák-magyar és a szerb „párharc”, továbbá a szerb kisebbség helyzete marginális kérdéssé vált.

\section{FELHASZNÁLT SZAKIRODALOM ÉS FORRÁSJEGYZÉK}

\section{Szakirodalom}

Cieger András (2001): A hatalomra jutott liberalizmus és az állam a dualizmus első felének magyar politikai gondolkodásában. Századvég 6.évf. 20. sz. http://www.c3.hu/scripta/szazadveg/20/ cieger.htm. Letöltés: 2015. június 26.

G. FODOR GÁBOR (2004): Gondoljuk újra a polgári radikálisokat. Budapest, L'Harmattan Kiadó. 149.

GaLÁntai József (2001): Magyarország az első világháborúban. Budapest, Korona Kiadó.

GYőri Szabó Róbert (2006): Kisebbség, autonómia, regionalizmus. Budapest, Osiris Kiadó.

Hajdú Zoltán: A Vajdaság 1910-1920 között. historia.hu (http://www.historia.hu/userfiles/ files/2010-012/Hajdu.pdf)

KATUs LÁszLó (1993): Egy kisebbségi törvény születése. Az 1868. évi nemzetiségi törvény évfordulójára. Regio 4. évf. 4. sz. 99-128.

Keegan, John (2010): Az első világháború. Budapest, Európa Könyvkiadó.

Kozma István - PAPp RicháRD (2004): Etnikai kölcsönhatásokés konfliktusok a Kárpát-medencében. Budapest, Gondolat - MTA.

Szeghő PAtrik (2009): Egy újravívott csata - A szerb szellemi elit és Ó-Szerbia kérdése (1912-1939). Trianoni Szemle 1. évf. 4. sz. 62-75.

Tilkovszky Lóránt (1998): Nemzetiségpolitika Magyarországon a 20. században. Debrecen, Csokonai Kiadó.

\section{Forrásjegyzék}

A Monarchia ultimátuma Szerbiának. - Forrás: tudasbazis.sulinet.hu (http://tudasbazis.sulinet. $\mathrm{hu} / \mathrm{hu} /$ tarsadalomtudomanyok/tortenelem/ magyar-tortenelmi-terkeptar/az-osztrak-magyarmonarchia-felbomlasa/forrasgyujtemeny)

Az 1868. évi XLIV. nemzetiségi törvény teljes szövege. Forrás: 1000ev.hu (http://www.1000ev.hu/index. php?a=3\&param $=5366$ )

Budapesti Hírlap 1914-1933. Forrás: Arcanum Digitális Tudománytár (http://adtplus.arcanum.hu/hu/ collection/BudapestiHirlap/)

Megszámláltattál - A magyar tragédia előérzete. Forrás: mandiner.blog.hu (http://mandiner.blog. hu/2014/07/16/megszamlaltattal_a_magyar_ tragedia_eloerzete)

\section{A tartalom kronológiája szerint sorrendbe állított napilapok és cikkeik}

\section{Budapesti Hírlap}

1914. július 1.: Az országgyűlés részvéte. 34. évf. 153. sz. 2-3.

1914. július 1.: A nyelvkérdés a közigazgatásban. 34 . évf. 153. sz. 5.

1914. július 18.: Szerb egyházi autonómia és a szerb pártok. 34. évf. 168. sz.

1914. július 27.: Magyarország harci kedve. 34. évf. 176. sz. 8.

1914. július 28.: A népszerü háború. 34. évf. 177. sz. 1.

1914. július 28.: A szerbek bünlajstroma. 34. évf. 177. sz. 8. 1914. július 29:: A király manifesztuma. 34. évf. 178. sz. 1.

1914. augusztus 23.: A monarkia ellenfelei. - A gyilkos szerbek. - Az offenzíva fölfüggesztése. 34. évf. 203. sz. 2.

\section{Délmagyarország}

1914. augusztus 12.: Hogy dolgozott Szerbia a monarchia egysége ellen. 3. évf. 198. sz. 3.

1914. augusztus 12.: Az ókeresztúri szerbek hazafiassága. 3. évf. 198. sz. 4.

1915. szeptember 2.: A Délvidék elpusztult községei. 4. évf. 213. sz. 5.

1917. július 29.: A föispán esküje és beszéde. 6. évf. 176. sz. 6-7.

1918. szeptember 3.: Szeged vármegye. 7. évf. 201. sz. 3.

1918. október 29.: Megkezdték Délmagyarország katonai kiürítését. 7. évf. 256. sz. 6.

Népszava 
1914. július 3.: A szerbek ellen. 42. évf. 155. sz. 6.

1917. szeptember 5.: A választójogért. 45. évf. 223. sz. 7.

1918. november 29.: A zombori bunyevácok nem haladnak együtt a szerbekkel. 46. évf. 283. sz. 8.

1918. december 13.: A szerbek átveszik a törvényszéket. - Temesvárott tilos a gyülekezés. - A magyar kormány rendeletei a megszállott területeken végre nem hajthatók. - A szerbek föloszlatták a nemzeti tanácsokat. 46. évf. 295. sz. 3.
Szegedi Napló

1914. július 1.: A bünbarlang. 37. évf. 155. sz. 1.

1914. október 6.: Szerb pópa búcsúztatója a bitófa előtt. 37. évf. 254. sz. 6.

1915. szeptember 3.: A hódoló küldöttség. Üzent a király Magyarországnak. 37. évf. 211. sz. 3-4.

1917. december 8.: A delegációk. 40 évf. 280. sz. 4.

1918. október 18.: A képviselőház ülése. 41.évf. 240.sz.2.

\section{Legújabb kiadványunk!}

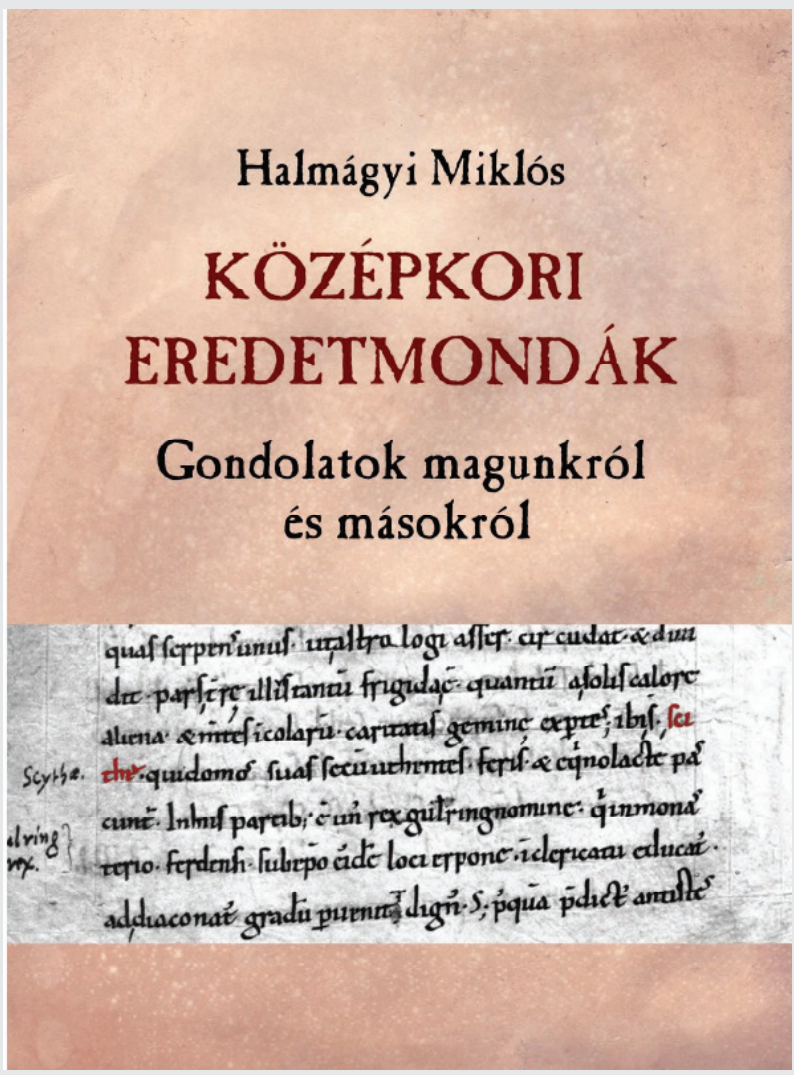

Miért fontos számunkra az első ezredforduló kora? A magyarság számára leginkább Szent István koronázása miatt, de 1000-ben vette fel a kereszténységet Izland, és ekkoriban szelte a tengert Leif Erikson hajója Grönlandtól nyugat felé, hogy partra szállion Vinlandon, vagyis Amerikában. Hogyan látták egymást ekkor a különféle európai népek fiai? Meddig terjedt a látókörük? Mit tartottak magukénak, és mit éreztek maguktól idegennek? Ezekre a kérdésekre keres választ ez a kötet, közelebb hozva a korszak több fontos történetírójának gondolatait. Olvashatunk csatakiáltásokról, harcelöttiimákról, hittéritésröl, világiaknyelvtudásról, idegenekre használt irodalmifordulatokról, végítélettel kapcsolatos gondolkodásról stb. 